\title{
PENGARUH SISTEM AKUNTANSI KEUANGAN DAERAH DAN STANDAR AKUNTANSI PEMERINTAH TERHADAP KUALITAS LAPORAN KEUANGAN PEMERINTAH
}

\author{
Hadi Jauhari \\ Ha.di@polsri.ac.id, \\ Jurusan Administrasi Bisnis, Politeknik Negeri Sriwijaya \\ Suhairi Hazisma \\ hlsuhairihazisma@gmail.com, \\ Jurusan Administrasi Bisnis, Politeknik Negeri Sriwijaya \\ Evada Dewata \\ Evada78@polsri.ac.id, \\ Jurusan Akuntansi, Politeknik Negeri Sriwijaya
}

\begin{abstract}
ABSTRAK
Penelitian ini mengeksplorasi pengaruh standar akuntansi pemerintah dan sistem akuntansi keuangan daerah sebagai faktor penting yang harus dipertimbangkan menyusun laporan keuangan yang bersinergi dengan peran sistem pengendalian intern. Populasi penelitian ini adalah pegawai yang bekerja di Badan Pengelola Keuangan dan Aset Daerah (BPKAD) Provinsi Sumatera Selatan, Indonesia. Teknik pengambilan sampel adalah purposive sampling dan diperoleh 46 responden yang mengisi secara lengkap kuesioner. Model analisis regresi yang digunakan adalah Moderated Regresion Analysis (MRA). Hasil penelitian menyatakan bahwa secara parsial, penerapan standar akuntansi pemerintah dan sistem akuntansi keuangan daerah berpengaruh positif signifikan terhadap kualitas laporan keuangan pemerintah, tetapi sistem pengendalian intern pemerintah tidak memoderasi pengaruh antara standar akuntansi pemerintah dan sistem akuntansi keuangan daerah terhadap kualitas laporan keuangan pemerintah daerah. Implikasi penelitian bahwa untuk mencapai kualitas laporan keuangan pemerintah yang relevan dan andal, diperlukan konsisten dalam menyajikan informasi laporan keuangan sesuai standar akuntansi pemerintah dan sistem akuntansi keuangan daerah harus bisa mengintegrasikan laporan keuangan daerah secara komprehensif.
\end{abstract}

Kata Kunci : Standar Akuntansi Pemerintah; Sistem Akuntansi Keuangan Daerah; Sistem Pengendalian Intern Pemerintah; Kualitas Laporan Keuangan Daerah.

\begin{abstract}
This research explores the influence of government accounting standards and regional financial accounting systems as important factors that must be considered in preparing financial reports that are in synergy with the role of the internal control system. The population of this study are employees who work at the Regional Financial and Asset Management Agency (BPKAD) of South Sumatra Province, Indonesia. The sampling technique was purposive sampling and obtained 46 respondents who filled out the questionnaire completely. The regression analysis model used is Moderated Regression Analysis (MRA). The results showed that partially, the application of government accounting standards and regional financial accounting systems had a significant positive effect on the quality of government financial reports, but the government's internal control system did not moderate the effect between government accounting standards and regional financial accounting systems on the quality of local government financial reports. The implication of the research is that to achieve the quality of relevant and reliable government financial reports, it is necessary to be consistent in presenting financial statement information following
\end{abstract}


government accounting standards and the regional financial accounting system must be able to integrate regional financial statements comprehensively.

Keywords - Government Accounting Standards; Regional Financial Accounting System; Government Internal Control System; Quality Of Regional Financial Reports.

\section{PENDAHULUAN}

Bagian Pemerintah Daerah, baik pemerintah pusat maupun pemerintah daerah memiliki kewajiban menyampaikan laporan pertanggungjawaban laporan keuangan yang berkualitas sesuai karakteristik kualitatif laporan keuangan (Peraturan Pemerintah, No 71 Tahun 2010). Laporan Keuangan Pemerintah Daerah (LKPD) setiap tahunnya mendapat penilaian dari Supreme Audit Board (BPK-RI) yang akan menunjukkan seberapa baik kualitas LKPD. According to the results of the Supreme Audit Board of perwakilan Sumatera Selatan, Indonesia atas LKPD sebagaimana disajikan dalam tabel 1 dibawah ini.

Tabel 1 Perkembangan LKPD Provinsi Sumatera Selatan

\begin{tabular}{|c|l|}
\hline $\begin{array}{c}\text { Tahun } \\
\text { Anggaran }\end{array}$ & \multicolumn{1}{c|}{ Opini BPK } \\
\hline 2007 & Wajar Dengan Pengecualian (WDP) \\
\hline 2008 & Wajar Dengan Pengecualian (WDP) \\
\hline 2009 & Wajar Dengan Pengecualian (WDP) \\
\hline 2010 & Wajar Dengan Pengecualian (WDP) \\
\hline 2011 & Wajar Dengan Pengecualian (WDP) \\
\hline 2012 & Wajar Dengan Pengecualian (WDP) \\
\hline 2013 & Wajar Dengan Pengecualian (WDP) \\
\hline 2014 & Wajar Tanpa Pengecualian dengan Paragraf Penjelas (WTP DPP) \\
\hline 2015 & Wajar Tanpa Pengecualian (WTP) \\
\hline 2016 & Wajar Tanpa Pengecualian (WTP) \\
\hline 2017 & Wajar Tanpa Pengecualian (WTP) \\
\hline 2018 & Wajar Tanpa Pengecualian (WTP) \\
\hline 2019 & Wajar Tanpa Pengecualian (WTP) \\
\hline
\end{tabular}

Sumber: Ikhtisar Hasil Pemeriksaan BPK-RI, 2020.

Berdasarkan tabel 1 dapat dilihat bahwa opini BPK tentang LKPD provinsi Sumatera Selatan mengalami peningkatan untuk tahun 2007 sampai tahun 2019 dari opini WDP menjadi opini WTP. Namun keberhasilan pencapaian opini ini tidak menjadikan pemerintah daerah menjadi lengah, karena dari hasil evaluasi BPK-RI tahun 2019, menunjukkan bahwa masih ada LKPD yang belum memperoleh opini WTP disebabkan oleh Penyajian laporan keuangan yang belum sesuai dengan Standar Akuntansi Pemerintahan (SAP), belum sepenuhnya diterapkan SAKD sehingga menyebabkan timbulnya kelemahan dalam sistem penyusunan laporan keuangan, kurang memadainya kompetensi Sumber Daya Manusia (SDM) pengelola keuangan 
pada pemerintah daerah, belum tertatanya barang milik negara/daerah dengan tertib, tidak sesuainya pelaksanaan pengadaan barang dan jasa dengan ketentuan yang berlaku.

Fenomena mengenai kualitas laporan keuangan pemerintah ini menjadi topik menarik untuk pengkajian lebih lanjut. Penelitian terdahulu mengenai standar akuntansi pemerintah terhadap kualitas LKPD masih menunjukkan hasil berbeda, seperti dilakukan oleh (Dewata et al,2017); (Sudiarianti, Ulupui \& Budiasih,2015); (Herzeqovina B, Erlina,2019) (Muthaher,2018) menyatakan bahwa standar akuntansi pemerintahan berpengaruh positif terhadap kualitas laporan keuangan pemerintah daerah. Sebaliknya (Nurlis,2018) dan (Aswar,2020), penerapan standar akuntansi pemerintah tidak memiliki hubungan yang signifikan dengan kualitas LKPD. Begitupun (Fikri, Inapty \& Martiningsih,2015) menyatakan penerapan standar akuntansi pemerintahan tidak berpengaruh terhadap kualitas laporan keuangan di Provinsi Nusa Tengggara Barat, Indonesia. Penelitian (Faradisa \& Khafid, 2017) dan (Dewi \& Hoesad,2020) juga menyatakan hal yang sama bahwa penerapan standar akuntansi pemerintahan tidak berpengaruh terhadap kualitas laporan keuangan.

Sistem Akuntansi Keuangan Daerah (SAKD) berdasarkan (Peraturan Menteri Dalam Negeri,No 21 Tahun 2011) merupakan serangkaian prosedur mulai dari proses pengumpulan data, pencatatan, pengikhtisaran, sampai dengan pelaporan keuangan, dalam rangka pertanggungjawaban pelaksanaan anggaran pendapatan dan belanja daerah. Penyataan disampaikan (Fauziyah, 2019); (Wati et al., 2014), (Thenikusuma \& Muis,2019) bahwa sistem akuntansi keuangan daerah berpengaruh positif terhadap kualitas laporan keuangan daerah, namun (Kartoprawiro \& Susanto, 2018) membuktikan bahwa sistem informasi akuntansi keuangan daerah tidak berpengaruh signifikan terhadap kualitas laporan keuangan.

Beberapa penelitian (Aswar,2020) dan (Dewi \& Hoesad,2020) menyatakan sistem pengendalian intern pemerintah berpengaruh signifikan terhadap kualitas LKPD. Untuk itu, penelitian ini mencoba menempatkan sistem pengendalian intern pemerintah sebagai variabel pemoderasi atas pengaruh penerapan standar akuntansi pemerintah dan sistem akuntansi keuangan daerah terhadap LKPD dengan asumsi sistem pengendalian intern memiliki peran pengendali untuk semua aktivitas yang berjalan, selain itu merupakan salah satu instrumen pemerintah yang memiliki job desk untuk mengawasi dan mengevaluasi suatu kegiatan di sektor publik (Tuanakotta, 2010:284), sehingga dapat memperkuat pengaruh variabel independen (penerapan standar akuntansi pemerintah dan sistem akuntansi keuangan daerah) terhadap variabel dependen. Oleh karena itu, tujuan dari penelitian ini adalah untuk: (1) menguji pengaruh penerapan standar akuntansi pemerintah dan sistem akuntansi keuangan 
daerah terhadap kualitas LKPD Provinsi Sumatera Selatan. 2) menguji pengaruh moderasi sistem pengendalian intern pemerintah pada hubungan antara penerapan standar akuntansi pemerintah dan sistem akuntansi keuangan daerah terhadap kualitas LKPD Provinsi Sumatera Selatan.

Penelitian in diharapkan dapat memberikan kontribusi teoritis yakni memberikan bukti empiris peningkatan kualitas laporan keuangan pemerintah melalui penerapan standar akuntansi pemerintah dan sistem akuntansi keuangan daerah dengan sistem pengendalian intern pemerintah sebagai variabel pemoderasi. Kontribusi praktis penelitian ini yakni dapat dijadikan sebagai pertimbangan dan masukan bagi pemerintah daerah Provinsi Sumatera Selatan dalam perumusan kebijakan peningkatan pengelolaan keuangan daerah.

\section{TINJAUAN PUSTAKA}

Stewardship teori menekankan bahwa pemerintah (pelayan) tidak termotivasi untuk tujuan individu tetapi lebih pada tujuan kepentingan organisasi yang menyediakan layanan publik (Godfrey et al., 2010). Teori ini lebih terkait tentang akuntabilitas yang dilakukan oleh pemerintah daerah (pelayan) kepada masyarakat dalam melaksanakan mandat. Salah satu bentuk penyampaian akuntabilitas pemerintah yaitu melalui pelaporan keuangan secara rutin dan berkualitas guna menjaga kepercayaan para pemangku kepentingan/para stakeholder. LKPD merupakan media akuntabilitas publik, yang berguna untuk mempertanggungjawabkan penggunaan sumber daya dan pelaksanaan kebijakan yang dilakukan oleh pemerintah. Kriteria dan unsur pembentuk kualitas laporan keuangan yang disebutkan dalam Kerangka Konseptual Akuntansi Pemerintahan paragraf 35 yang terdiri dari: (1) relevan (2) andal (3) dapat diperbandingkan, dan (4) dapat dipahami (Peraturan Pemerintah, No 71 Tahun 2010).

Stewardship teori mengarahkan perwujudan akuntabilitas oleh Steward kepada masyarakat dapat dilakukan dengan pelaporan keuangan yang mengikuti standar akuntansi pemerintah sebagai salah satu bentuk pertanggungjawaban pengelolaan keuangan daerah yang transparan dan akuntabel. Penerapan standar akuntansi pemerintah harus dilakukan secara konsisten sebagai upaya meningkatkan kualitas LKPD. Jika pemerintah daerah berkomitmen penuh dalam menyusun laporan keuangan berdasarkan prinsip-prinsip standar akuntansi pemerintah maka kualitas laporan keuangan menjadi semakin baik. Penelitian mengenai pengaruh penerapan standar akuntansi pemerintahan terhadap kualitas laporan keuangan telah dilakukan oleh (Dewata et al,2017) dan (Herzeqovina B, Erlina,2019) bahwa standar akuntansi pemerintahan berpengaruh positif terhadap kualitas laporan keuangan pemerintah 
daerah. Standar akuntansi pemerintah merupakan persyaratan dalam upaya meningkatkan kualitas LKPD. Berdasarkan uraian tersebut dapat dirumuskan hipotesis berikut:

H1: Penerapan standar akuntansi pemerintah berpengaruh positif terhadap kualitas LKPD.

Penerapan sistem akuntansi keuangan daerah bertujuan untuk meningkatkan akuntabilitas dan keandalan LKPD, lemahnya penerapan sistem akuntansi keuangan daerah dapat menyebabkan kualitas laporan keuangan yang dihasilkan juga kurang relevan dan Andal untuk pengambilan keputusan, seperti diungkap (Fauziyah, 2019), (Hanifa, 2016), sistem akuntansi keuangan daerah berpengaruh positif terhadap kualitas laporan keuangan daerah. Adanya konsistensi penerapan sistem akuntansi keuangan daerah, maka kemungkinan resiko kekeliruan atau kesalahan dapat diminimalisir dalam pencatatan dan pelaporan keuangan. Untuk dapat menghasilkan laporan keuangan pemerintah yang relevan dan andal, pemerintah daerah harus memiliki sistem akuntansi keuangan daerah yang handal juga. Sistem akuntansi yang lemah menyebabkan laporan keuangan yang dihasilkan juga kurang handal dan kurang relevan untuk pembuatan keputusan. Berdasarkan uraian tersebut dapat dirumuskan hipotesis berikut:

H2: Penerapan sistem akuntansi keuangan daerah berpengaruh positif terhadap kualitas LKPD.

Sistem pengendalian intern pemerintah diselenggarakan secara menyeluruh baik di lingkungan Pemerintah Pusat dan Pemerintah Daerah (Peraturan Pemerintah, No 60 Tahun 2008). Penerapan Standar Akuntansi Pemerintah akan dapat berjalan dengan efektif dan efisien, jika didukung sistem pengendalian intern pemerintah yang memadai dan akan menghasilkan LKPD yang berkualitas, seperti diungkap Indriasih (2014), efektifitas sistem pengendalian intern pemerintah menjadi penyebab utama lemahnya kualitas laporan keuangan pemerintah daerah. Pendapat (Yusniyar, 2016) bahwa sistem pengendalian intern berpengaruh positif terhadap kualitas LKPD. Adanya penerapan sistem pengendalian intern pemerintah akan memberikan arah dan kontrol yang baik bahwa standar akuntansi pemerintah dilaksanakan sebagaimana mestinya, sehingga kualitas LKPD bisa tercapai sesuai yang dipersyaratkan yaitu relevan, andal, dapat diperbandingkan dan dapat dipahami. Berdasarkan uraian tersebut maka dapat dirumuskan hipotesis:

H3: Sistem pengendalian intern pemerintah memoderasi pengaruh standar akuntansi pemerintah dengan kualitas laporan keuangan. 
Sistem pengendalian intern pemerintah dapat meningkatkan transparansi dan akuntabilitas dalam proses penerapan sistem akuntansi keuangan daerah serta peningkatan kualitas LKPD. Dengan mengoptimalkan sistem pengendalian intern pemerintah secara efektif dan efisien maka dapat menjadi mediator sistem akuntansi keuangan daerah dalam meningkatkan kualitas LKPD. Sistem pengendalian intern pemerintah harus diterapkan dengan baik untuk memastikan bahwa sistem akuntansi keuangan daerah terlaksana dengan baik. Semakin baik penerapan sistem pengendalian intern pemerintah suatu instansi, maka upaya menerapkan sistem akuntansi keuangan daerah dalam pelaporan keuangan yang berkualitas dapat ditingkatkan. Sebaliknya, apabila Instansi kurang optimal dalam menerapkan sistem pengendalian intern pemerintah maka akan tidak maksimal penerapan sistem akuntansi keuangan daerah. Untuk itu, dengan dukungan sistem pengendalian intern pemerintah yang kuat tentunya akan meningkatkan kualitas LKPD, seperti diungkap (Fauziyah, 2019), pengendalian inter pemerintah mampu memoderasi pengaruh sistem akuntansi keuangan daerah terhadap kualitas laporan keuangan. Berdasarkan uraian tersebut maka dapat dirumuskan hipotesis:

H4: Sistem pengendalian intern memoderasi pengaruh sistem akuntansi keuangan daerah dengan kualitas laporan keuangan.

\section{METODE}

Jenis penelitian ini adalah penelitian survey (survey research) berupa penjelasan dan pengujian hipotesa (explanatory) dengan menggunakan metode deskriptif dan eksploratori tentang penerapan standar akuntansi pemerintah, sistem akuntansi keuangan daerah, kualitas LKPD dengan sistem pengendalian intern pemerintah sebagai variabel moderating. Variabel moderasi adalah variabel yang bersifat memperkuat atau memperlemah hubungan antara variabel independent terhadap variabel dependent (Ghozali, 2013:55).

Populasi penelitian ini adalah pegawai yang bekerja di Badan Pengelola Keuangan Dan Aset Daerah (BPKAD) Provinsi Sumatera Selatan. Teknik pengambilan sampel yang digunakan dalam penelitian ini adalah purposive sampling, dengan kriteria responden yaitu para pegawai pada bidang akuntansi dan pelaporan keuangan daerah, perencanaan anggaran daerah, perbendaharaan, dan pengelolaan Barang Milik Daerah (BMD) yang terkait dalam 
pengelolaan keuangan daerah yang berada dilingkup kantor BPKAD Provinsi Sumatera Selatan sebanyak 50 orang.

Berikut ini definisi operasional variabel penelitian disajikan dalam tabel 2.

Tabel 2 Operasional Variabel

\begin{tabular}{|c|c|c|}
\hline Variabel & Dimensi & Indikator \\
\hline \multirow[t]{2}{*}{$\begin{array}{l}\text { Kualitas LKPD } \\
\text { (KLKPD) }\end{array}$} & Relevan & $\begin{array}{l}\text { 1. Sesuai standar akuntansi } \\
\text { 2. Dapat memprediksi kejadian masa datang } \\
\text { 3. Tepat waktu dalam penyusunan } \\
\text { 4. Dapat digunakan mengambil keputusan }\end{array}$ \\
\hline & Andal & $\begin{array}{l}\text { 5. Objektivitas dalam penyajian laporan } \\
\text { 6. Laporan teruji kebenaran } \\
\text { 7. Memenuhi kebutuhan pengguna laporan } \\
\text { 8. Laporan tidak berpihak pada kepentingan }\end{array}$ \\
\hline \multirow{2}{*}{$\begin{array}{l}\text { Sumber } \\
\text { (Peraturan } \\
\text { Pemerintah, No } \\
\text { 71 Tahun } \\
\text { 2010) }\end{array}$} & $\begin{array}{l}\text { Dapat } \\
\text { dibandingkan }\end{array}$ & $\begin{array}{l}\text { 9. Dapat dibandingkan pada periode sebelumnya } \\
\text { 10. Penyusunan berpedoman pada SAP }\end{array}$ \\
\hline & Dapat dipahami & $\begin{array}{l}\text { 11. Dapat dipahami oleh pengguna dan disusun } \\
\text { berdasarkan pemahaman pengguna } \\
\text { 12. Penyusunan secara sistematis }\end{array}$ \\
\hline \multirow{9}{*}{$\begin{array}{l}\text { Standar } \\
\text { Akuntansi } \\
\text { Pemerintah } \\
\text { (SAP) }\end{array}$} & $\begin{array}{l}\text { PSAP No.01 } \\
\text { Penyajian Laporan } \\
\text { Keuangan }\end{array}$ & $\begin{array}{l}\text { 1. Basis akrual pengakuan aset } \\
\text { 2. Basis akrual pengakuan kewajiban dan ekuitas }\end{array}$ \\
\hline & $\begin{array}{l}\text { PSAP No. } 02 \\
\text { Laporan Realisasi } \\
\text { Anggaran } \\
\text { Kas }\end{array}$ & $\begin{array}{l}\text { 3. Basis kas pengakuan pendapatan } \\
\text { 4. Basis kas pengakuan belanja dan pembiayaan }\end{array}$ \\
\hline & \begin{tabular}{|l|} 
PSAP No. 03 \\
Laporan Arus Kas \\
\end{tabular} & $\begin{array}{ll}\text { 5. Penyajian arus kas sesuai SAP } \\
\text { 6. } & \text { Metode langsung arus kas } \\
\end{array}$ \\
\hline & $\begin{array}{l}\text { PSAP No. } 04 \\
\text { Catatan atas } \\
\text { laporan Keuangan }\end{array}$ & $\begin{array}{ll}\text { 7. Penyajian catatan atas laporan keuangan setiap } \\
\text { periode } \\
\text { 8. Penyusunan catatan atas laporan keuangan } \\
\text { secara lengkap }\end{array}$ \\
\hline & $\begin{array}{l}\text { PSAP No. } 05 \\
\text { Akuntansi } \\
\text { Persediaan }\end{array}$ & $\begin{array}{l}\text { 9. Pengakuan persediaan } \\
\text { 10. } \text { Pencatatan persediaan }\end{array}$ \\
\hline & \begin{tabular}{|l|} 
PSAP No. 06 \\
Akuntansi Investasi \\
\end{tabular} & $\begin{array}{l}\text { 11. Penilaian investasi metode biaya } \\
\text { 12. Penilaian investasi metode ekuitas }\end{array}$ \\
\hline & \begin{tabular}{ll|} 
PSAP No. 07 \\
Akuntansi Aset \\
Tetap \\
\end{tabular} & $\begin{array}{l}\text { 13. Pengklasifikasian aset tetap } \\
\text { 14. Penilaian aset tetap }\end{array}$ \\
\hline & $\begin{array}{|lr|}\text { PSAP No. } \quad 08 \\
\text { Akuntansi } \\
\text { Kontruksi dalam } \\
\text { pengerjaan }\end{array}$ & $\begin{array}{l}\text { 15. Pengungkapan informasi KDP } \\
\text { 16. Pemindahan KDP }\end{array}$ \\
\hline & $\begin{array}{l}\text { PSAP No. } 09 \\
\text { Akuntansi } \\
\text { kewajiban }\end{array}$ & $\begin{array}{l}\text { 17. Pengakuan kewajiban saat peminjaman } \\
\text { diterima } \\
\text { 18. Pencatatan kewajiban }\end{array}$ \\
\hline
\end{tabular}




\begin{tabular}{|c|c|c|}
\hline \multirow[b]{3}{*}{\begin{tabular}{|l|} 
Sumber \\
(Peraturan \\
Pemerintah, No \\
71 Tahun \\
2010)
\end{tabular}} & $\begin{array}{l}\text { PSAP No. } 10 \\
\text { Koreksi kesalahan }\end{array}$ & $\begin{array}{l}\text { 19. Koreksi kesalahan berdasarkan SAP } \\
\text { 20. Koreksi kesalahan tidak berulang }\end{array}$ \\
\hline & $\begin{array}{l}\text { PSAP No. } 11 \\
\text { Laporan Keuangan } \\
\text { Konsolidasian }\end{array}$ & $\begin{array}{l}\text { 21. Penyajian konsolidasi pada periode pelaporan } \\
\text { 22. Pelaporan konsolidasi semua entitas }\end{array}$ \\
\hline & $\begin{array}{l}\text { PSAP No. } 12 \\
\text { Laporan } \\
\text { Oprasional }\end{array}$ & $\begin{array}{l}\text { 23. Basis akrual pengakuan pendapatan } \\
\text { 24. Basis akrual pengakuan beban }\end{array}$ \\
\hline \multirow[t]{3}{*}{$\begin{array}{l}\text { Sistem } \\
\text { Akuntansi } \\
\text { Keuangan } \\
\text { Daerah } \\
\text { (SAKD) }\end{array}$} & $\begin{array}{ll}\text { Kesesuaian } & \text { Sistem } \\
\text { Akuntansi } & \\
\text { keuangan } & \text { standar } \\
\text { akuntansi } & \\
\text { pemerintah } & \\
\end{array}$ & $\begin{array}{l}\text { 1. Kesesuaian standar akuntansi pemerintah } \\
\text { 2. Menggunakan analisis transaksi }\end{array}$ \\
\hline & $\begin{array}{lr}\text { Prosedur } & \\
\text { pencatatan } & \\
\text { akuntansi } & \text { dengan } \\
\text { pencatatan } & \text { standar } \\
\text { akuntansi } & \text { yang } \\
\text { berlaku } & \\
\end{array}$ & $\begin{array}{l}\text { 3. } \\
\text { 4. } \text { Prangidentifikasian pencatatan } \\
\text { 5. Pencatatan secara kronologis } \\
\text { 6. } \\
\text { Pengklasifikasian teransaksi }\end{array}$ \\
\hline & $\begin{array}{l}\text { Pembuatan laporan } \\
\text { keuangan yang } \\
\text { dilaporkan secara } \\
\text { periodik. }\end{array}$ & $\begin{array}{l}\text { 7. Pengklasifikasian sesuai pos-pos akuntansi } \\
\text { 8. Sistem Pengendalian pencatatan } \\
\text { 9. Penyusunan laporan keuangan sesuai priode } \\
\text { 10. Pelaporan sesuai secara konsisten }\end{array}$ \\
\hline \multirow{4}{*}{$\begin{array}{l}\text { Sistem } \\
\text { Pengendalian } \\
\text { Intern } \\
\text { Pemerintah } \\
\text { (SPIP) }\end{array}$} & $\begin{array}{l}\text { 1. Lingkungan } \\
\text { Pengendalian }\end{array}$ & $\begin{array}{l}\text { 1. Peraturan tertulis dan lisan } \\
\text { 2. Standar kopetensi tugas dan fungsi }\end{array}$ \\
\hline & 2. Penilaian Resiko & $\begin{array}{l}\text { 3. Mengindentifikasi dan menganalisis risiko } \\
\text { 4. Menerapkan batas dan penentuan toleransi }\end{array}$ \\
\hline & $\begin{array}{l}\text { 3. Kegiatan } \\
\text { Pengendalian }\end{array}$ & $\begin{array}{l}\text { 5. Memastikan melaksanakan arahan dari pimpinan } \\
\text { 6. Transaksi dan aktivitas didukung otorisasi pihak } \\
\text { berwenang } \\
\text { 7. Menerapkan pemisahan tugas }\end{array}$ \\
\hline & $\begin{array}{l}\text { 4. Informasi Dan } \\
\text { Komunikasi }\end{array}$ & $\begin{array}{l}\text { 8. Menyediakan sarana komunikasi } \\
\text { 9. Mengelola, mengembangkan, memperbaharui } \\
\text { sistem informasi } \\
\text { 10. Melaksanakan sistem akuntansi }\end{array}$ \\
\hline $\begin{array}{l}\text { Sumber } \\
\text { Peraturan } \\
\text { Pemerintah, No } \\
60 \text { tahun } 2008\end{array}$ & $\begin{array}{l}\text { 5. Pemantauan } \\
\text { Pengendalian } \\
\text { Intern }\end{array}$ & $\begin{array}{l}\text { 11. Dapat menilai kualitas kinerja } \\
\text { 12. Melakukan pemeriksaan terhadap catatan } \\
\text { akuntansi }\end{array}$ \\
\hline
\end{tabular}

Pengukuran data untuk mengukur persepsi responden maka menggunakan skala Likert lima poin yaitu: 1 = sangat tidak setuju (STS), 2 = tidak setuju (TS), $3=$ netral (N), $4=$ setuju (S), 5 = sangat setuju (SS). Kriteria yang digunakan untuk mengetahui kondisi variabel-variabel penelitian secara menyeluruh dapat dilihat melalui rerata skor sebagai berikut: a) sangat tidak baik $(1,00-1,80)$; b) tidak baik $(1,80-2,60)$ : c) cukup baik $(2,60-3,40)$; d) baik $(3,40-$ $4,20)$ dan e) sangat baik $(4,20-5,00)$. 
Model analisis regresi yang digunakan dalam penelitian ini adalah Moderated Regresion Analysis (MRA).

$$
\mathrm{KLKPD}=\beta_{0}+\beta_{1} \mathrm{SAP}+\beta_{2} \mathrm{SKAD}+\varepsilon
$$

Model Regresi Berganda Moderasi Hierarki (dengan variabel moderasi):

Persamaan dengan variabel moderasi dan interaksi adalah:

$$
\begin{aligned}
& \mathrm{KLKPD}=\beta_{0}+\beta_{1} \mathrm{SAP}+\beta_{2} \mathrm{X}_{3}+\beta_{3} \mathrm{SAP} * \mathrm{SPIP}+\varepsilon \ldots \\
& \mathrm{KLKPD}=\beta_{0}+\beta_{1} \mathrm{SKAD}+\beta_{2} \mathrm{X}_{3}+\beta_{3} \mathrm{SKAD} * \mathrm{SPIP}+\varepsilon
\end{aligned}
$$

\section{HASIL DAN PEMBAHASAN}

Dari 50 kuesioner yang disebar, hanya sebanyak 46 kuesioner yang kembali dan dapat diolah. Dengan demikian dapat diketahui bahwa tingkat pengembalian kuesioner sebesar 92\%. Tabel 3 berikut adalah hasil statistik deskriptif yang memberikan gambaran statistik dari variabel penelitian ini:

Tabel 3 Statistik Deskriptif

\begin{tabular}{|llllll|}
\hline & $\mathrm{N}$ & Minimum & Maximum & Mean & Std. Deviation \\
KLKP & 46 & 3.92 & 5.00 & 4.3804 & .43092 \\
SAP & 46 & 3.83 & 5.00 & 4.3188 & .42954 \\
SAKD & 46 & 3.50 & 4.60 & 3.9870 & .34808 \\
SPIP & 46 & 3.33 & 4.67 & 3.8515 & .35181 \\
\hline
\end{tabular}

Sumber: Output SPSS, 2020

Variabel kualitas laporan keuangan pemerintah (KLKP) memiliki rerata skor 4,38, artinya penilaian responden terhadap kualitas LKPD Provinsi Sumatera Selatan tergolong sangat baik. Indikator Relevan (no pernyataan 1) dan Andal (no penyataan 5) dengan nilai rerata skor 4,5 dan 4,5 memiliki nilai tertinggi diantara indikator lainnya, hal ini menunjukan bahwa BPKAD) Provinsi Sumatera Selatan telah memenuhi prasyarat normatif yang diperlukan agar LKPD berkualitas sepertin yang dikehendaki, yaitu relevan, andal, dapat diperbandingkan, dan dapat dipahami. Rerata skor variabel standar akuntansi pemerintahan (SAP) yaitu sebesar 4.32 masuk kategori sangat baik, indikator PSAP No. 04 catatan atas laporan keuangan (no penyataan 8) memiliki rerata nilai skor tertinggi sebesar 4,6, hal ini menunjukan bahwa penyusunan catatan atas laporan keuangan sudah disusun dan disajikan secara lengkap sesuai prinsip-prinsip akuntansi yang berlaku. 
Selanjutnya variabel sistem akuntansi keuangan daerah memiliki rerata skor sebesar 3,98 dengan nilai indikator tertinggi pada indikator kesesuaian sistem akuntansi keuangan dengan standar akuntansi pemerintah (no pernyataan 1), hal ini berarti penerapan sistem akuntansi keuangan daerah sudah sesuai mengikuti standar akuntansi pemerintah. Terakhir untuk variabel moderasi sistem pengendalian intern pemerintah (SPIP) tergolong baik, dilihat dari total rerata skor 3,85, dengan nilai indikator tertinggi sebesar 4.19 yaitu lingkungan pengendalian (no pernyataan 1), hal ini mengindikasikan bahwa lingkungan pengendalian pemerintah daerah Provinsi Sumatera Selatan sudah baik.

Hasil pengujian Uji Validitas dan Uji Reliabilitas terhadap data seperti pada tabel 4 berikut:

Tabel 4 Hasil Uji Validitas Variabel Penelitian

\begin{tabular}{|l|c|c|c|}
\hline No Item Pernyataan & r Hitung & r Tabel & Kesimpulan \\
\hline Kualitas Laporan Keuangan Pemerintah Daerah (Y) & \multicolumn{1}{l|}{} \\
\hline KLKP1 & 0.799 & 0.284 & Valid \\
\hline KLKP2 & 0.815 & 0.284 & Valid \\
\hline KLKP3 & 0.791 & 0.284 & Valid \\
\hline KLKP4 & 0.713 & 0.284 & Valid \\
\hline KLKP5 & 0.876 & 0.284 & Valid \\
\hline KLKP6 & 0.841 & 0.284 & Valid \\
\hline KLKP7 & 0.796 & 0.284 & Valid \\
\hline KLKP8 & 0.765 & 0.284 & Valid \\
\hline KLKP9 & 0.854 & 0.284 & Valid \\
\hline KLKP10 & 0.786 & 0.284 & Valid \\
\hline KLKP11 & 0.814 & 0.284 & Valid \\
\hline KLKP12 & 0.803 & 0.284 & Valid \\
\hline Standar Akuntansi Pemerintah $(X 1)$ & \multicolumn{5}{|l|}{} \\
\hline SAP1 & 0,500 & 0.284 & Valid \\
\hline SAP2 & 0,669 & 0.284 & Valid \\
\hline SAP3 & 0,676 & 0.284 & Valid \\
\hline SAP4 & 0.654 & 0.284 & Valid \\
\hline SAP5 & 0.869 & 0.284 & Valid \\
\hline SAP6 & 0.917 & 0.284 & Valid \\
\hline SAP7 & 0.798 & 0.284 & Valid \\
\hline SAP8 & 0.680 & 0.284 & Valid \\
\hline SAP9 & 0.782 & 0.284 & Valid \\
\hline SAP10 & 0.898 & 0.284 & Valid \\
\hline SAP11 & 0.686 & 0.284 & Valid \\
\hline SAP12 & 0.680 & 0.284 & Valid \\
\hline SAP13 & 0.869 & 0.284 & Valid \\
\hline SAP14 & 0.859 & 0.284 & Valid \\
\hline SAP15 & 0.926 & 0.284 & Valid \\
\hline SAP16 & 0.789 & 0.284 & Valid \\
\hline SAP17 & 0.790 & 0.284 & Valid \\
\hline \multicolumn{3}{|l|}{} \\
\hline
\end{tabular}




\begin{tabular}{|c|c|c|c|}
\hline SAP18 & 0.846 & 0.284 & Valid \\
\hline SAP19 & 0.831 & 0.284 & Valid \\
\hline SAP20 & 0.863 & 0.284 & Valid \\
\hline SAP21 & 0.751 & 0.284 & Valid \\
\hline SAP22 & 0.911 & 0.284 & Valid \\
\hline SAP23 & 0.897 & 0.284 & Valid \\
\hline SAP24 & 0.825 & 0.284 & Valid \\
\hline \multicolumn{4}{|c|}{ Sistem Akuntansi Keuangan Daerah (X2) } \\
\hline SAKD1 & 0.683 & 0.284 & Valid \\
\hline SAKD2 & 0.702 & 0.284 & Valid \\
\hline SAKD3 & 0.646 & 0.284 & Valid \\
\hline SAKD4 & 0.735 & 0.284 & Valid \\
\hline SAKD5 & 0.626 & 0.284 & Valid \\
\hline SAKD6 & 0.837 & 0.284 & Valid \\
\hline SAKD7 & 0.692 & 0.284 & Valid \\
\hline SAKD8 & 0.912 & 0.284 & Valid \\
\hline SAKD9 & 0.824 & 0.284 & Valid \\
\hline SAKD10 & 0.724 & 0.284 & Valid \\
\hline \multicolumn{4}{|c|}{ Sistem Pengendalian Intern Pemerintah (M) } \\
\hline SPI1 & 0.748 & 0.284 & Valid \\
\hline SPI2 & 0.779 & 0.284 & Valid \\
\hline SPI3 & 0.775 & 0.284 & Valid \\
\hline SPI4 & 0.708 & 0.284 & Valid \\
\hline SPI5 & 0.792 & 0.284 & Valid \\
\hline SPI6 & 0.698 & 0.284 & Valid \\
\hline SPI7 & 0.608 & 0.284 & Valid \\
\hline SPI8 & 0.548 & 0.284 & Valid \\
\hline SPI9 & 0.666 & 0.284 & Valid \\
\hline SPI10 & 0.694 & 0.284 & Valid \\
\hline SPI11 & 0.679 & 0.284 & Valid \\
\hline SPI12 & 0.602 & 0.284 & Valid \\
\hline
\end{tabular}

Sumber: Output SPSS, 2020

Instrumen dinyatakan valid jika angka korelasi yang diperoleh lebih besar dari angka kritik ( $r$ hitung $>r$ tabel), dan nilai $r$ tabel sebesar 0,284 maka pertanyaan dalam kuisioner tersebut dikatakan valid. Selanjutnya hasil uji reliabilitas yang telah dilakukan pada tiap variabel independen seperti pada table 5 berikut :

Tabel 5 Hasil Uji Reliabilitas

\begin{tabular}{|l|c|l|}
\hline \multicolumn{1}{|c|}{ Variabel } & $\begin{array}{c}\text { Nilai } \\
\text { Reliabilitas }\end{array}$ & Keterangan \\
\hline Kualitas Laporan Keuangan Pemerintah Daerah (Y) & 0.949 & reliabel. \\
\hline Standar Akuntansi Pemerintah (X1) & 0.970 & reliabel. \\
\hline Sistem Akuntansi Keuangan Daerah (X2) & 0.692 & reliabel. \\
\hline Sistem Pengendalian Intern Pemerintah (M) & 0.791 & reliabel. \\
\hline
\end{tabular}

Sumber: Output SPSS, 2020 
Suatu variabel dikatakan kurang baik jika memberikan nilai koefisien Alpha Cronbach < 0,60, sedangkan 0,7 dapat diterima dan di atas 0,8 adalah baik (Priyatno, 2012:187). Nilai $r$ hitung lebih besar dari 0,6 dapat disimpulkan pernyataan kuesioner sebagai alat ukur variabel penelitian yang digunakan adalah reliabel.

Berikut ini ditampilkan analisis regresi variabel standar akuntansi pemerintah dan sistem akuntansi keuangan daerah terhadap variabel kualitas LKPD.

Tabel 6 Hasil Uji Regresi Linear

Coefficients $^{\mathrm{a}}$

\begin{tabular}{|c|c|c|c|c|c|}
\hline \multirow[b]{2}{*}{ Model } & \multicolumn{2}{|c|}{$\begin{array}{c}\text { Unstandardized } \\
\text { Coefficients }\end{array}$} & \multicolumn{3}{|l|}{$\begin{array}{l}\text { Standardized } \\
\text { Coefficients }\end{array}$} \\
\hline & B & Std. Error & Beta & $\mathrm{t}$ & Sig. \\
\hline 1 (Constant) & .269 & .474 & & .567 & .574 \\
\hline SAP & .340 & .121 & .339 & 2.804 & .008 \\
\hline SAKD & .663 & .150 & .535 & 4.430 & .000 \\
\hline R Square & & & & & \\
\hline Adjusted R Square & & & & & \\
\hline F hitung & & & & & \\
\hline Sign & & & & & \\
\hline
\end{tabular}

a. Dependent Variable: KLKPD

Sumber: Hasil Output SPSS,2020

Dari tabel 6 diketahui hasil koefisien penerapan standar akuntansi pemerintah terhadap kualitas LKPD memiliki nilai positif 0,340, nilai t-hitung sebesar 2,804 dan taraf signifikansi 0,008. Nilai t-hitung yang lebih besar dari t-tabel $(2,016)$ berarti $\mathbf{H 1}$ diterima yaitu penerapan standar akuntansi pemerintah berpengaruh positif terhadap kualitas LKPD. Selanjutnya hasil koefisien penerapan sistem akuntansi keuangan daerah terhadap kualitas LKPD memiliki nilai positif 0,663, nilai t-hitung 4,430 lebih besar dari t-tabel 2,016 dan taraf signifikansi 0,000, ini berarti $\mathbf{H 2}$ diterima yaitu penerapan sistem akuntansi keuangan daerah berpengaruh positif terhadap kualitas LKPD. Dari perhitungan di atas diperoleh F-hitung sebesar 37,866 dan nilai F-tabel pada tarif $\alpha=5 \%$ dan df $1=\mathrm{k}-1=3-1=2$, df $2=\mathrm{n}-\mathrm{k}=46-3=43$ diperoleh F-tabel sebesar 3,214 atau 37,866>3,214, artinya penerapan standar akuntansi pemerintah dan sistem akuntansi keuangan daerah secara simultan berpengaruh terhadap kualitas LKPD. Diketahui juga nilai Adjusted R Square sebesar 0.621, ini berarti 62,1\% kualitas LKPD Provinsi Sumatera Selatan dipengaruhi oleh variabel standar akuntansi pemerintah dan sistem akuntansi keuangan daerah, sedangkan selebihnya 37,9\% dipengaruhi oleh variabel lainnya yang tidak diteliti dalam penelitian ini.

Berikut ini analisis MRA variabel standar akuntansi pemerintah, sistem pengendalian intern pemerintah dan variable interaksi terhadap variabel kualitas LKPD. 
Tabel 7. Hasil Uji Moderating Regression Analysis

Coefficients $^{\mathrm{a}}$

\begin{tabular}{|c|c|c|c|c|c|}
\hline \multirow[t]{2}{*}{ Model } & \multicolumn{2}{|c|}{$\begin{array}{l}\text { Unstandardized } \\
\text { Coefficients }\end{array}$} & $\begin{array}{c}\text { Standardized } \\
\text { Coefficients }\end{array}$ & $\mathrm{t}$ & Sig. \\
\hline & B & Std. Error & Beta & & \\
\hline 1 (Constant) & 2.936 & 6.271 & & .468 & .642 \\
\hline SAP & .054 & 1.354 & .054 & .040 & .968 \\
\hline SPIP & -.211 & 1.646 & -.172 & -.128 & .899 \\
\hline SAP*SPIP & .121 & .352 & .824 & .344 & .733 \\
\hline
\end{tabular}

a. Dependent Variable: KLKPD

Sumber: Hasil Output SPSS,2020

Berdasarkan tabel 7 pada uji statistik di atas, maka diperoleh nilai t-hitung untuk sistem pengendalian internal memoderasi pengaruh standar akuntansi pemerintah terhadap kualitas LKPD adalah sebesar 0,344 sedangkan t-tabel 2,016, hasil tersebut menunjukkan t-hitung< $\mathrm{t}$ tabel $(0,344<2,016)$ dan sig >0,05 $(0,733>0,05)$, maka H3 ditolak artinya bahwa sistem pengendalian internal tidak mampu memoderasi pengaruh standar akuntansi pemerintah terhadap kualitas LKPD Provinsi Sumatera Selatan.

Berikut ini analisis Moderating Regression Analysis variabel sistem akuntansi keuangan daerah, sistem pengendalian intern pemerintah dan variable Interaksi terhadap variabel kualitas LKPD.

Tabel 8 Hasil Uji Moderating Regression Analysis

Coefficients $^{\mathrm{a}}$

\begin{tabular}{|ccccccc|}
\hline \multirow{2}{*}{ Model } & \multicolumn{2}{c}{ Unstandardized } & \multicolumn{2}{c|}{ Standardized } \\
Coefficients & Coefficients & & \\
& & B & Std. Error & Beta & t & Sig. \\
1 & (Constant) & -7.359 & 6.865 & & -1.072 & .290 \\
& SAKD & 2.500 & 1.619 & 2.020 & 1.544 & .130 \\
& SPIP & 2.304 & 1.819 & 1.881 & 1.266 & .212 \\
& SAKD*SPIP & -.461 & .427 & -2.620 & -1.080 & .286 \\
\hline
\end{tabular}

a. Dependent Variable: KLKPD

Sumber: Hasil Output SPSS,2020

Berdasarkan tabel 8 di atas, maka nilai t-hitung untuk sistem pengendalian internal memoderasi pengaruh sistem akuntansi keuangan daerah terhadap kualitas LKPD adalah sebesar -1,080 sedangkan t-tabel 2,016. Hasil tersebut menunjukkan bahwa t-hitung < ttabel ($1,080<2,016)$ dan sig > 0,05 (0,286 > 0,05), maka H4 ditolak artinya bahwa sistem pengendalian internal tidak mampu memoderasi pengaruh sistem akuntansi keuangan daerah terhadap kualitas LKPD Provinsi Sumatera Selatan. 


\section{Pengaruh Penerapan Standar Akuntansi Pemerintah Terhadap Kualitas LKPD}

Berdasarkan hasil pengujian hipotesis H1 diterima yaitu penerapan standar akuntansi pemerintah berpengaruh positif signifikan terhadap kualitas LKPD. Temuan ini membuktikan standar akuntansi pemerintah menjadi salah satu mekanisme pengendalian dalam pembuatan laporan keuangan agar dapat disajikan dan diungkapkan secara wajar dan berkualitas. Hasil penelitian ini dibuktikan dari nilai indikator PSAP No. $04 \mathrm{c}$ atatan atas laporan keuangan (no penyataan 8) memiliki nilai skor tertinggi sebesar 4,6 dibandingkan indikator lain, yang berarti laporan keuangan sudah didukung penjelasan atas semua akun transaksi khususnya mungkin mengandung informasi yang dapat mempunyai potensi kesalahpahaman. Catatan atas laporan keuangan telah memuat referensi pos-pos laporan keuangan sehingga menjadi informasi untuk memudahkan pengguna dalam memahami laporan keuangan

Hasil penelitian ini membuktikan standar akuntansi pemerintah merupakan prinsip akuntansi yang harus diterapkan untuk penyusunan dan penyajian LKPD, jika standar akuntansi pemerintah diterapkan secara tepat sebagai bentuk pemenuhan kewajiban pemerintah dibidang akuntabilitas keuangan menjadi salah satu penentu kualitas LKPD. Hasil penelitian ini juga mendukung (Dewata et al, 2017) dan (Herzeqovina B, Erlina, 2019) bahwa standar akuntansi pemerintahan berpengaruh positif terhadap kualitas laporan keuangan pemerintah daerah. Namun bertentangan dengan (Aswar, 2020); (Fikri, Inapty \& Martiningsih, 2015) dan (Dewi \& Hoesad,2020) bahwa penerapan standar akuntansi pemerintahan tidak berpengaruh terhadap kualitas laporan keuangan. Hasil penelitian ini memberikan implikasi bagi pemerintah daerah untuk mencapai kualitas LKPD yang sesuai dengan karakterisitik kualitatif laporan keuangan (Peraturan Pemerintah, No 71 Tahun 2010), maka untuk tetap konsisten menyajikan informasi laporan keuangan secara komprehensip sesuai peraturan pemerintah yaitu menerapkan akuntansi berbasis akrual dalam penyusunan semua laporan keuangan.

\section{Pengaruh Sistem Akuntansi Keuangan Daerah Terhadap Kualitas LKPD}

Hasil pengujian regresi menunjukkan hipotesis $\mathbf{H 2}$ diterima yaitu penerapan sistem akuntansi keuangan daerah berpengaruh positif signifikan terhadap kualitas LKPD. Ini berarti kualitas LKPD yang dihasilkan sangat dibantu oleh sistem akuntansi keuangan daerah yang dimiliki Provinsi Sumatera Selatan baik dalam pengelolaan maupun pelaporan laporan keuangan. Ini dibuktikan dari indikator penerapan sistem akuntansi keuangan daerah no 1 yaitu kesesuaian sistem akuntansi keuangan dengan standar akuntansi pemerintah 
memiliki skor rataan 3,98. Penerapan sistem akuntansi keuangan daerah memiliki peran dalam meningkatkan kualitas LKPD Provinsi Sumatera Selatan karena melalui penerapan sistem akuntansi keuangan daerah, akan dihasilkan laporan keuangan yang cepat, akurat dan tepat waktu. Hasil penelitian ini sejalan dengan penelitian (Fauziyah, 2019) dan (Thenikusuma \& Muis,2019), akan tetapi tidak searah dengan temuan dari (Kartoprawiro \& Susanto, 2018) membuktikan bahwa sistem informasi akuntansi keuangan daerah tidak berpengaruh signifikan terhadap kualitas laporan keuangan. Hasil penelitian ini memberikan implikasi bagi pemerintah daerah bahwa untuk mendapatkan laporan keuangan sebagai sarana evaluasi kinerja maka perlu adanya sistem akuntansi keuangan daerah yang dirancang dan dibuat aturannya yang dapat mengintegrasikan laporan keuangan dan perlu didukung oleh sumber daya manusia yang mampu menjalankan sistem akuntansi keuangan daerah secara keseluruhan.

\section{Penerapan Standar Akuntansi Pemerintah dan Kualitas LKPD dengan Sistem pengendalian Intern Pemerintah Sebagai variabel Moderating}

Hipotesis H3 ditolak, bahwa sistem pengendalian intern pemerintah tidak memoderasi pengaruh standar akuntansi pemerintah terhadap kualitas LKPD. Ini berarti bahwa sistem pengendalian intern pemerintah tidak memperkuat atau memperlemah penerapan standar akuntansi pemerintah untuk menciptakan kualitas LKPD, karena pada dasarnya penerapan standar akuntansi pemerintah itu sendiri sudah cukup kuat untuk menciptakan kualitas LKPD sebagaimana tercantum dalam hipotesis pertama. Hasil penelitian ini tidak berhasil membuktikan pengaruh mediasi yang diberikan oleh sistem pengendalian intern pemerintah terhadap hubungan antara standar akuntansi pemerintah dan kualitas LKPD Provinsi Sumatera Selatan, hal ini menunjukan sistem pengendalian intern pemerintah belum berjalan sesuai fungsinya yakni sebagai controlling dan monitoring, dapat dibuktikan dari hasil statistik jawaban responden (no pernyataan 1) memiliki nilai indikator terendah sebesar 2,239 yaitu pada indikator pengendalian resiko, pemerintah daerah belum sepenuhnya melakukan analisis resiko atas temuan-temuan yang terjadi dalam pelaksanaan aktivitas pengelolaan dan pelaporan keuangan. Implikasi penelitian bagi pemerintah daerah bahwa kualitas laporan keuangan tidak hanya dinilai dari efektivitas pengendalian internnya saja, namun aparatur pemerintah sebagai pelaksana harus mampu memenuhi aspek-aspek lain seperti nilai integritas, etika dan kepatuhan terhadap peraturan perundang-undangan agar dapat menghasilkan laporan keuangan yang dinilai berkualitas. Peningkatan sistem pengendalian 
intern pemerintah dapat dilakukan dengan meningkatkan indikator lingkungan pengendalian yang menunjukkan keseluruhan sikap organisasi yang memengaruhi kesadaran dan perilaku personel organisasi.

\section{Penerapan Sistem Akuntansi Keuangan Daerah dan Kualitas LKPD dengan Sistem pengendalian Intern Pemerintah Sebagai variabel Moderating}

Hipotesis $\mathbf{H} 4$ ditolak, bahwa sistem pengendalian intern pemerintah tidak memoderasi pengaruh sistem akuntansi keuangan daerah terhadap kualitas laporan keuangan. Hasil penelitian ini menunjukkan bahwa sistem pengendalian intern pemerintah tidak signifikan dalam memediasi pengaruh tidak langsung sistem akuntansi keuangan daerah terhadap kualitas LKPD. Jadi penerapan sistem akuntansi keuangan daerah walaupun tidak dibarengi dengan sistem pengendalian intern pemerintah yang baik tetap mampu menghasilkan laporan keuangan yang berkualitas. Ditolaknya hipotesis ini dapat dijelaskan, karena belum maksimalnya sistem pengendalian intern pemerintah Provinsi Sumatera Selatan, khususnya pada indikator penilaian resiko (nilai indikator terendah 2,239) yaitu kemampuan mengidentifikasi secara efisien dan efektif risiko yang dapat menghambat pencapaian tujuan organisasi baik yang bersumber dari dalam maupun luar instansi. Masih adanya salah satu unsur sistem pengendalian intern pemerintah yaitu unsur penilaian risiko yang mempunyai rata-rata tidak baik, berdampak sistem pengendalian intern pemerintah tidak mampu memperkuat hubungan sistem akuntansi keuangan daerah terhadap kualitas LKPD. Hasil penelitian ini memberikan implikasi bahwa masih belum memadainya efektifitas sistem pengendalian intern pemerintah Provinsi Sumatera Selatan, terutama pada unsur penilaian risiko agar menjadi perhatian khusus bagi kepala BPKAD dan Pemerintahan Provinsi Sumatera Selatan.

\section{SIMPULAN}

Hasil penelitian ini membuktikan standar akuntansi pemerintah diterapkan secara bersama-sama dengan sistem akuntansi keuangan daerah mampu meningkatkan kualitas LKPD, walaupun sistem pengendalian intern pemerintah ternyata belum mampu memediasi pengaruh standar akuntansi pemerintah dan sistem akuntansi keuangan daerah terhadap kualitas LKPD. Menjadi faktor penting untuk menjaga kualitas laporan keuangan, sesuai persyaratan Badan Pemeriksa Keuangan Indonesia (BPK-RI) dan harus dipertimbangkan untuk mengidentifikasi kelemahan sistem pengendalian intern pemerintah khususnya unsur 
penilaian risiko sesuai tupoksi pada Badan Pengelola Keuangan Dan Aset Daerah (BPKAD)

Provinsi Sumatera Selatan.

\section{Keterbatasan Penelitian}

Penelitian ini memiliki beberapa keterbatasan. Pertama, penelitian ini dilakukan hanya dilakukan pada 1 instansi pemeintah daerah Provinsi Sumatera Selatan, sehingga hasilnya tidak dapat digeneralisasi. Kedua, penelitian ini menggunakan kuesioner untuk mendapatkan data, sehingga peneliti tidak dapat menggali lebih dalam. Penelitian selanjutnya bisa menambahkan metode pengumpulan dengan wawancara untuk memperoleh informasi lebih banyak dan analisis selanjutnya bisa membandingkan antar provinsi yang memiliki hasil opini kualitas LKPD yang berbeda.

\section{DAFTAR PUSTAKA}

Aswar, K. (2020). Assessing the impact of influencing factors on the quality of local government financial statements. Journal of Economics Finance and Accounting, 7(1), 18. https://doi.org/10.17261/pressacademia.2020.1176

Dewata, E., Natoen, A., Jauhari, H., Sari, Y., \& Hartiyani, S. J. (2017). Determining Factors Of The Quality Of Local Government Financial Statements. Proceeding 3rd Sriwijaya Economics, Accounting, and Business Conference 2017, November, 405-429.

Dewi, R. J. H. (2020). the Effect of Government Accounting Standards and Government Internal Control Systems on the Quality of Local Government Financial Statements. International Journal of Innovative Research and Advanced Studies (IJIRAS), 7(1), 108111. https://doi.org/10.35310/jass.v1i02.243

Faradisa, A. N., \& Khafid, M. (2017). The Effect of Competency and The Implementation of Standard on The Quality of Financial Statement with Control System as A Moderating Variable. Accounting Analysis Journal, 6(3), 394-406. https://doi.org/10.15294/aaj.v6i3.17972

Fauziyah, E. M. (2019). Pengaruh Penerapan Sistem Akuntansi Keuangan Daerah, Kompetensi Aparatur Pemerintah dan Pemanfaatan Teknologi Informasi Terhadap Kualitas Laporan Keuangan Dengan Sistem Pengendalian Internal Sebagai Variabel Moderasi (Pada Organisasi Perangkat Daerah di K. Jurnal Riset Akuntansi Tirtayasa, 4(2), 196-209.

Fikri, A., Inapty, B. A., \& Martiningsih, S. P. (2015). Pengaruh penerapan standar akuntansi pemerintahan, kompetensi aparatur dan peran audit internal terhadap kualitas informasi laporan keuangan dengan sistem pengendalian intern sebagai variabel moderating (Studi empiris pada SKPD-SKPD di Pemprov. NTB). Simposium Nasional Akuntansi XVIII. https://doi.org/10.1017/CBO9781107415324.004

Hanifa, L. (2016). Pengaruh Kompetensi Pengelola Keuangan dan Sistem Akuntansi Keuangan Daerah Terhadap Kualitas Laporan Keuangan. Jurnal Progres Ekonomi Pembangunan, 1(2), 65-80.

Herzeqovina B, Erlina, S. E. (2019). Factors Affecting the Quality of Regional Financial Statements in RAO ( Regional Apparatus Organization ) of Deli Serdang Regency with the Governmental Internal Control System as a Moderating Variable. International Journal of 
Research \& Review, 6(6), 409-417.

Kartoprawiro, S., \& Susanto, Y. (2018). Analisis Terhadap Kinerja Laporan Keuangan Pemerintah Daerah Kabupaten Musi Rawas. Jurnal Manajemen Dan Bisnis Sriwijaya, 16(1), 1-14. https://doi.org/10.29259/jmbs.v16i1.6242

Muthaher, O. (2018). Government Accounting Standard, Human Capacity, Internal Control System And Financial Supervision As A Quality Analysis Of Government Financial Statements. Fokus Ekonomi, 14(1), 186-200. http://ejournal.stiepena.ac.id/index.php/fe

Nurlis (2018). The Effect of The Government Accounting Standards Implementation and Apparatus Competency on the Quality of the Local Government Financial Reporting (Case Study at Klaten District Government). Research Journal of Finance and Accounting, 9, 6369.

Peraturan Menteri Dalam Negeri Nomor 21 Tahun 2011 Tentang Perubahan Kedua Atas Peraturan Menteri Dalam Negeri Nomor 13 Tahun 2006 Tentang Pedoman Pengelolaan Keuangan Daerah, (2011).

Peraturan Pemerintah Nomor 71 Tahun 2010 tentang Standar Akuntansi Pemerintahan., (2010).

Peraturan Pemerintah Republik Indonesia Nomor 60 Tahun 2008 Tentang Sistem Pengendalian Intern Pemerintah, (2008).

Sudiarianti, N. M., Ulupui, I. G. K. A., \& Budiasih, I. G. A. (2015). Pengaruh Kompetensi Sumber Daya Manusia Pada Penerapan Sistem Pengendalian Intern Pemerintah dan Standar Akuntansi Pemerintah Serta Implikasinya Pada Kualitas Laporan Keuangan Daerah. Simposium Nasional Akuntansi XVIII.

Thenikusuma, K., \& Muis, N. (2019). The Effect of Implementation Regional Financial Accounting System, Human Resource Competency and Infrastructure Facilities to the Quality of Financial Report. Available at SSRN: https://ssrn.com/abstract=3313401 or http://dx.doi.org/10.2139/ssrn.3313401

Wati, K. D., Herawati, N. T., \& Sinarwati, N. K. (2014). Pengaruh Kompetensi SDM, Penerapan SAP, dan SAKD terhadap Kualitas Laporan Keuangan Daerah. E-Journal S1 Ak Universitas Pendidikan Ganesha, 2(1), 1-11.

Yusniyar, D. dan S. A. (2016). Pengaruh Penerapan Sistem Akuntansi Pemerintahan dan Pengendalian Intern Terhadap Good Governance Dan Dampaknya Pada Kualitas Laporan Keuangan (Studi Pada Skpa Pemerintah Aceh). Jurnal Magister Akuntansi Pascasarjana, $5(2), 100-115$. 